\title{
Separate and combined effects of cadmium(Cd) and nonylphenol(NP) on growth and antioxidative enzymes in Hydrocharis dubia (BI.) Backer
}

\section{Zhen Ke}

Wuhan University

Donghan Wang

Wuhan University

Zhonghua Wu ( $\nabla$ wuzhonghua@whu.edu.cn )

Wuhan University https://orcid.org/0000-0003-0810-7470

\section{Research Article}

Keywords: nonylphenol, cadmium, Hydrocharis dubia (BI.) Backer, compound pollution

Posted Date: August 23rd, 2021

DOI: https://doi.org/10.21203/rs.3.rs-689161/v1

License: (c) (i) This work is licensed under a Creative Commons Attribution 4.0 International License.

Read Full License 


\section{Abstract}

Cadmium (Cd) is listed as a priority pollutant, and nonylphenol(NP) is a common organic pollutant in water environment. However, the ecological risks of combined pollution of $\mathrm{Cd}$ and NP have not been fully elucidated. In this study, the effects of $\mathrm{Cd}(0.01,0.1,0.5,1,5 \mathrm{mg} / \mathrm{L}), \mathrm{NP}(0.1,0.5,1,5,10 \mathrm{mg} / \mathrm{L})$ and Cd-NP $(0.01+0.1,0.01+1.0,0.5+0.1,0.5+1.0,5+0.1,5+1.0 \mathrm{mg} / \mathrm{L})$ on growth and physiology of Hydrocharis Dubia (BI.) Backer were studied. The results showed that the toxicity of $H$. dubia showed a dosedependent effect. Growth level and chlorophyll contents of $H$. dubia induced by NP stress alone showed a certain toxicant excitatory effect. It meant that low concentrations of toxins promote plants growth, high concentrations of toxins inhibit plants growth. The increase of $\mathrm{H}_{2} \mathrm{O}_{2}$ content and the decrease of soluble protein content in the plant indicated that both $\mathrm{Cd}$ and NP caused oxidative damage to $\mathrm{H}$. dubia. Under the stress, the antioxidant defense systems were activated, the activity of superoxide dismutase (SOD) was significantly decreased. The activity of catalase (CAT) reacted negatively under stress alone, but increased significantly under combined stress. The activity of peroxidase (POD) increased, which was used to alleviate the damage caused by toxics stress. The joint toxicity evaluation showed that the joint toxicity of $\mathrm{Cd}$ and NP to $\mathrm{H}$. dubia was antagonistic when the concentrations of $\mathrm{Cd}+\mathrm{NP}$ were $0.01+0.1$ $\mathrm{mg} / \mathrm{L}$ and $0.01+1 \mathrm{mg} / \mathrm{L}$. At $0.5+0.1 \mathrm{mg} / \mathrm{L}$ and $0.5+1 \mathrm{mg} / \mathrm{L}, \mathrm{Cd}$ and NP had a strong synergistic effect on H. dubia.

\section{Introduction}

Cadmium(Cd) is a typical environmental pollutant with high toxicity. It can be biohazardous even if the concentration in the range of 0.001 to $0.1 \mathrm{mg} / \mathrm{L}$ (Chellaiah, 2018). As a large industrial country, China's Cd mineral resources rank first in the world, accounting for $23 \%$ of the world's total. The total amount of $\mathrm{Cd}$ discharged into the environment by industrial "Three Wastes" is more than 680 tons every year. Cd's produce, use and diffusion in the modern environment have increased worldwide (Rehman et al., 2018), resulting in a serious situation of Cd pollution. With the development of heavy metal smelting, mining and other human activities, $\mathrm{Cd}$ releases into the soil and migrated to rivers and groundwater (Kersten et al., 2017). This leads to the increase of $\mathrm{Cd}$ concentration in water. It's reported that the concentration of $\mathrm{Cd}$ was estimated to be significantly higher than that of chromium( $\mathrm{Cr}$ ), nickel $(\mathrm{Ni})$, copper $(\mathrm{Cu})$, zinc $(\mathrm{Zn})$ in the Pearl River Estuary (Ye et al., 2020). Cd is harmful in plants, it can be absorbed and accumulated through the food chain in plant tissues, affecting plant's normal growth and development (Rizwan et al., 2016; Yan et al., 2021). Effects of Cd on aquatic plants has been paid more and more attention. It reported that the growth inhibition, damage of photosynthetic system and oxidative damage of Eichhornia crassipes and Lemna minor L. all showed photo-toxicity under Cd stress (Chaudhary and Sharma, 2019; Melignani et al., 2019).

Nonylphenol (NP) is a toxic heteromorphic compound, and it is one of the most important intermediates in the petrochemical and organic synthesis industries, mainly used to produce antioxidants, lubricant additives and non-ionic surfactants (Deng et al., 2019; Sun et al., 2021). As a large country of NP production and use, China's annual use of NP accounts for $10 \%$ of the world's use of NP (Gao et al., 
2014). In recent years, the detection frequency of NP is very high and even detected in drinking water (Catav et al., 2020; Zhou et al., 2015). NP can accumulate in algae, fish and other aquatic organisms due to its high lipophilicity and cause persistent damage to organisms (Zhou et al., 2019). The basic toxicity of NP is mainly related to changes in cell membrane permeability and oxidative stress (Pretorius et al., 2016). NP exerted a stronger inhibitory effect on cell growth, photosynthesis, and it contributed oxidative stress on Chlorella pyrenoidosa and Scenedesmus obliquus (Yang et al., 2021). However, the effects of NP on aquatic plants are unknown.

In today's environment, Cd and NP have been found frequently in lakes, rivers and oceans, and Cd and NP will cause compound pollution to water environment. Zheng et al. studied the interaction between $\mathrm{Cd}$ and NP in zebrafish males, and found that Cd and NP had antagonistic effects on reproductive physiology (Zheng et al., 2019). Additionally, Shi studied the effects of Cd and NP pollution on ryegrass and found that the combination of $\mathrm{Cd}$ and high concentration of NP reduced the inhibition of $\mathrm{Cd}$ under cocontaminated stress (Shi et al., 2018). Several studies have reported the effects of combined Cd and NP pollution on aquatic animal fish, including SOD and endocrine systems damage (Yang and Fang, 2012). But data on the joint toxicity of NP and Cd to plants, especially aquatic plants, are scarce.

Hydrocharis dubia (BI.) Backer, is one kind of perennial floating aquatic plant, grows in the fresh water or the salty water, distributes in south China, central China, southwest and so on fields. Its wide distribution range and large biomass as well as its ability to purify contaminated water make it an excellent aquatic plant for water monitoring and remediation (Liu et al., 2020). The present work aimed to:(1) investigate the effects of $\mathrm{Cd}$ and NP on the growth of $\mathrm{H}$. dubia alone and in combination, and to explore the mode of action of their combined ecotoxicological effects. (2) study the responses of Cd, NP and Cd-NP treatment to $H$. dubia's antioxidant systems, explore their toxicity mechanisms. This research's conclusion will offer a reference for the pollution control of heavy metals and organic pollutants, and a basis for ecological toxicity effects and ecological safety assessment of combined pollution on aquatic plants.

\section{Materials And Methods}

\subsection{Cultivation and treatment of $H$. dubia}

H. dubia plants picked from a freshwater lake-Donghu $\left(30^{\circ} 33.41^{\prime} \mathrm{N}, 114^{\circ} 22.59^{\prime} \mathrm{E}\right)$, Wuhan, Hubei Province. Before the experiment began, $H$. dubia plants cultivated in a greenhouse pond at a density of about 20 plants per $\mathrm{m}^{2}$. After two-week of cultivation, each plant (with 3-5 leaves, height no more than $20 \mathrm{~cm}$ ) was thoroughly cleaned, then moved to a climate chamber for acclimatization for 3 days. Plant's laboratory conditions were that $10 \%$ Hoagland's solution, $26 \pm 1^{\circ} \mathrm{C}$ with a $16 / 8$ light/dark cycle and a photon flux density of $120 \pm 20 \mu \mathrm{mol} / \mathrm{m}^{2} / \mathrm{s}$ (Zhong et al., 2018).

\subsection{Toxicants and experimental design}

The toxicants were $\mathrm{CdCl}_{2} \cdot 2.5 \mathrm{H}_{2} \mathrm{O}$ and nonylphenol $\left(\mathrm{C}_{15} \mathrm{H}_{24} \mathrm{O}\right)$. The $\mathrm{CdCl}_{2} \cdot 2.5 \mathrm{H}_{2} \mathrm{O}$ was analytical reagent (supplier: Sinopharm Chemical Reagent Co., Ltd., Shanghai, China), the nonylphenol (guaranteed 
reagent) was obtained from Shanghai Macklin Biochemical Co., Ltd., Shanghai, China.

Three treatments (Cd, NP and Cd-NP) and two controls (blank control and solvent control) set in the experiment. According to the environmental concentrations of the toxicants (Islam et al., 2015), Cd was set at $0.01,0.1,0.5,1.0,5 \mathrm{mg} / \mathrm{L}, \mathrm{NP}$ was set at $0.1,0.5,1.0,5,10 \mathrm{mg} / \mathrm{L}$. According to a single toxicity test, low, medium and high concentrations of $\mathrm{Cd}(0.01,0.5$ and $5 \mathrm{mg} / \mathrm{L})$ were mixed with NP concentrations $(0.1$ and $1 \mathrm{mg} / \mathrm{L})$, respectively. Their joint concentrations $(\mathrm{Cd}+\mathrm{NP})$ were $0.01+0.1,0.01+1.0,0.5+0.1$, $0.5+1.0,5+0.1$ and $5+1.0 \mathrm{mg} / \mathrm{L}$. The blank control (healthy control) was treated with $10 \%$ Hoagland culture solution of the same volume $(5 \mathrm{~L})$. All concentrations of NP were assisted by $100 \mu \mathrm{L}$ ethanol to make sure that the ethanol content was not more than $0.002 \%$, which had negligible effects on $\mathrm{H}$. dubia (Toyama et al., 2018). Both concentration treatment and control was set to three repetitions for 14 days. The experimental conditions were the same as described above for the pre-cultures and tanks were positioned in a random way. Solutions were changed every $48 \mathrm{~h}$ to keep up approximately constant concentrations of toxicants and nutrients. After 14 days of exposure, harvested plants and determined various parameters.

\subsection{Estimation of $H$. dubia growth}

After 14 days, plants were rinsed with distilled water. After being dried on filter paper, every plant was measured individually and weighed. Morphological indexes of the $\mathrm{H}$. dubia included Fresh weight, Ramet number, Leaf number, Maximal Leaf length, Maximal Leaf width and Root length, all of which were measured with a scale (accuracy $0.1 \mathrm{~cm}$ ).

\subsection{Photosynthetic pigments measurements}

Photosynthetic pigments were determined using a method described by Jampeetong and Brix (Jampeetong and Brix, 2009) with some changes. Plant leaves $(0.05 \mathrm{~g}, \mathrm{FW})$ were cut into many pieces, ground, and placed in 10-mL flasks. Then, the extraction of chlorophyll is done in $10 \mathrm{~mL} 95 \%(\mathrm{v} / \mathrm{v})$ alcohol. Flasks were placed for $24 \mathrm{~h}$ and light-free. The chlorophyll content in the plant leaves was determined with a spectrophotometer at 470,649 and $665 \mathrm{~nm}$ for chlorophyll a, chlorophyll b and carotenoids, respectively. All spectrophotometric analyses were conducted in a final volume of $3 \mathrm{~mL}$ by using a MAPADA UV-1200 spectrophotometer (Shanghai Meipuda Instrument Co. Ltd., Shanghai, China).

\subsection{Measurement of malonaldehyde (MDA) content}

The determination of MDA content in leaves can be used to evaluate the level of lipid peroxidation in plants. The trichloroacetic acid (TBA) method (Cang and Zhao, 2013) was used to measure MDA content. Weigh $0.05 \mathrm{~g}$ of plant leaves, ground with $2 \mathrm{~mL} 10 \%$ trichloroacetic acid (TCA). The grinding fluid was centrifuged at $4^{\circ} \mathrm{C}$ at $4000 \mathrm{rpm}$ for $10 \mathrm{~min} .1 .5 \mathrm{~mL}$ supernatant mixed with $1.5 \mathrm{~mL} 0.6 \%$ TBA solution, shaken and reacted in a boiling water bath for $30 \mathrm{~min}$. Then cooled rapidly in the ice bath and centrifuged at $4000 \mathrm{rpm}$ at $4^{\circ} \mathrm{C}$ for $15 \mathrm{~min}$. The supernatant was taken and measured the light absorption values at $450 \mathrm{~nm}, 532 \mathrm{~nm}$ and $600 \mathrm{~nm}$. The MDA content in the leaves was calculated by the formula. 


\subsection{Measurement of and hydrogen peroxide $\left(\mathrm{H}_{2} \mathrm{O}_{2}\right)$ content and enzyme activities}

$0.1 \mathrm{~g}$ fresh plant leaves mixed with precooled phosphoric acid buffer $(50 \mathrm{mM}, \mathrm{pH} 7.8$, containing $1 \% \mathrm{PVP})$ in a precooled mortar. The slurry was centrifuged at $4^{\circ} \mathrm{C}$ for $10000 \mathrm{~g}$ for $10 \mathrm{~min}$, the supernatant collected in $4^{\circ} \mathrm{C}$, refrigerator was used for the determination of superoxide dismutase (SOD), catalase (CAT), peroxidase (POD), $\mathrm{H}_{2} \mathrm{O}_{2}$ and soluble protein.

The method of titanium sulfate colorimetry to test $\mathrm{H}_{2} \mathrm{O}_{2}$ content (Cang and Zhao, 2013). $1.4 \mathrm{~mL}$ extract mixed with $1.4 \mathrm{~mL} 5 \%(\mathrm{~W} / \mathrm{V})$ titanium sulfate. The sample was left for $10 \mathrm{~min}$, then centrifuged at $4^{\circ} \mathrm{C}$ for $12000 \mathrm{r} / \mathrm{min}$ for $10 \mathrm{~min}$. Then taken the supernatant, the absorbance was measured at $410 \mathrm{~nm}$ by ultraviolet photometer. The $\mathrm{H}_{2} \mathrm{O}_{2}$ content in plant tissues per unit mass was calculated with the standard curve of absorbance value.

The method of nitrogen blue tetrazolium (NBT) photoreduction method (Cang and Zhao, 2013) to test SOD activity. 50\% inhibition of NBT photochemical reduction was an enzyme activity unit. The reaction mixture for SOD determination contained enzyme extract from plant tissues, methionine (Met) solution (130 mM), $50 \mathrm{mM}$ phosphate buffer (pH 7.8), NBT solution $(750 \mu \mathrm{M})$, EDTA-Na $_{2}(100 \mu \mathrm{M})$, riboflavin (20 $\mu \mathrm{M})$ and distilled water. After the reaction stopped, the absorbance value of the reaction solution was tested at $560 \mathrm{~nm}$ immediately, and calculated SOD activity.

The method of spectrophotometry to test CAT activity (Cang and Zhao, 2013). The decrease of 0.1 of the absorbance value of the reaction mixture at $240 \mathrm{~nm}$ per minute defined as a unit of CAT enzyme activity. The reaction mixture included enzyme extract from plant tissues, $20 \mathrm{mM}$ phosphate buffer $(\mathrm{pH} 7.8$, containing $1 \% \mathrm{PVP})$, distilled water, and $\mathrm{H}_{2} \mathrm{O}_{2}$ solution ( $\left.0.1 \mathrm{M}\right)$.

Guaiacol method to determine the activity of POD (Cang and Zhao, 2013). An enzyme activity unit (U/g. min FW) of POD was defined as a 0.01 increase in the light absorption value of the reaction mixture at $470 \mathrm{~nm}$ per minute. The reaction mixture contained enzyme extract from plant tissues, phosphoric acid buffer ( $100 \mathrm{mM}, \mathrm{PH} 6.0)$, guaiacol solution, and $\mathrm{H}_{2} \mathrm{O}_{2}$ solution (30\%).

\subsection{Measurement of soluble protein content}

The soluble protein content was determined by Coomassie Brilliant Blue G-250 staining (Bradford, 1976). $0.1 \mathrm{~mL}$ of sample extract mixed with $5 \mathrm{~mL}$ of Coomassie Bright Blue G-250 protein reagent in the test tube. Two minutes later, the absorbance was measured at $595 \mathrm{~nm}$ with blank as control. The protein content was calculated by the standard curve and absorption, and then the protein content was calculated according to the formula.

\subsection{Joint toxicity assessment method}


Abott formula (Gatidou and Thomaidis, 2007) was used to evaluate the combined toxicity of Cd and NP.

The widely used model was used to compare the expected and observed inhibitory effects. In this model, the expected inhibitory rate of combined pollution is expressed as a percentage of $\mathrm{C}_{\text {exp }}$, calculated as follows:

$C_{\exp }=A+B-A B / 100$

$A$ and $B$ are the inhibition levels caused by toxic substances acting alone. Inhibition rates (RI) at toxicant mixing were calculated as follows:

$\mathrm{RI}=$ Observed inhibition $/ \mathrm{C}_{\exp }$

Interaction effects were evaluated by comparing $\mathrm{RI}$ with 1 : $\mathrm{RI}>1$ represents synergistic action, $\mathrm{RI}=1$ shows simple summation, and $\mathrm{RI}<1$ represents antagonism between the two toxicants.

\subsection{Statistical analyses}

All the data were expressed as mean \pm standard deviation. SPSS21.0 statistical analysis software was used to conduct One-way analysis of variance (ANOVA) and Duncan test at $\mathrm{P}=0.05$ confidence level. Levene's test used for the homogeneity analysis of variance. Sigmaplot12.5 software was used for drawing.

\section{Results}

\subsection{Morphology and growth index}

After 14 days' exposure, under the NP-only stress, the growth indexes of $\mathrm{H}$. dubia in the experimental groups had a decreasing trend, and showed obvious damage effect (Table 1). Low dose of NP $(\leq 0.5$ $\mathrm{mg} / \mathrm{L}$ ) had no significant effect on the growth of $H$. dubia. However, at higher concentrations, except the number of ramet, other growth indexes of $H$. dubia decreased significantly.

In the $\mathrm{Cd}$ groups, the growth and morphological indexes of $H$. dubia showed significant damage characteristics. At higher concentrations $(\geq 0.5 \mathrm{mg} / \mathrm{L})$, fresh weigh of ramet decreased significantly $(P \otimes 0.05)$. At the highest concentration $(5 \mathrm{mg} / \mathrm{L})$, the plant was dead. The total leaf number, the root length, the maximum leaf width, and the maximum leaf length of the plant were significantly lower than those of the control group (Pख0.05). The root of $H$. dubia treated with high concentration $(1 \mathrm{mg} / \mathrm{L})$ was seriously decayed and the root length could not be measured.

Under combined stress, at Cd + NP $0.5+0.1 \mathrm{mg} / \mathrm{L}$, the fresh weight of plant decreased significantly $(\mathrm{P}<$ 0.05), and the fresh weight of mother plant and ramet showed a similar trend. The plants died in the highest concentrations, the growth indexes couldn't be measured (Table 1). At Cd + NP $5+0.1 \mathrm{mg} / \mathrm{L}$, the ramet number, the maximum leaf length, leaf width and the leaf number in treatment groups reach the 
significant level $(P<0.05)$. The root length of $H$. dubia treated with $C d+N P(0.01+0.1 \mathrm{mg} / \mathrm{L}$ and $0.01+1$ $\mathrm{mg} / \mathrm{L})$ was significantly lower than that of control group $(P<0.05)$.

\section{Table 1}

Result of Cd, NP and their mixture (Cd + NP) on H. dubia's Whole plant fresh weigh, Ramet fresh weigh(g), Maximum Leaf width $(\mathrm{cm})$, Maximum Leaf-Length $(\mathrm{cm})$, Ramet number, Root Length $(\mathrm{cm})$, Leaf number, after 14 day's exposure. $\mathrm{N}$ is for NP, $\mathrm{C}$ is for $\mathrm{Cd}, \mathrm{M}$ is for their mixtures. 


\begin{tabular}{|c|c|c|c|c|c|c|c|}
\hline treatment & $\begin{array}{l}\text { Whole } \\
\text { plant fresh } \\
\text { weigh(g) }\end{array}$ & $\begin{array}{l}\text { Ramet } \\
\text { fresh } \\
\text { weigh(g) }\end{array}$ & $\begin{array}{l}\text { Maximum } \\
\text { Leaf- } \\
\text { width(cm) }\end{array}$ & $\begin{array}{l}\text { Maximum } \\
\text { Leaf- } \\
\text { Length(cm) }\end{array}$ & $\begin{array}{l}\text { Ramet } \\
\text { number }\end{array}$ & $\begin{array}{l}\text { Root } \\
\text { Length } \\
\text { (cm) }\end{array}$ & $\begin{array}{l}\text { Leaf } \\
\text { number }\end{array}$ \\
\hline 0 & $\begin{array}{l}14.83 \pm \\
10.36^{b}\end{array}$ & $\begin{array}{l}9.65 \pm \\
8.90^{b}\end{array}$ & $\begin{array}{l}7.13 \pm 0.35 \\
b\end{array}$ & $6.90 \pm 0.20^{b}$ & $\begin{array}{l}15.67 \\
\pm \\
10.79^{b}\end{array}$ & $\begin{array}{l}13.13 \\
\pm 4.97^{c}\end{array}$ & $\begin{array}{l}33.00 \pm \\
17.78^{b}\end{array}$ \\
\hline C 0.01 & $\begin{array}{l}11.98 \pm \\
6.71^{\mathrm{ab}}\end{array}$ & $\begin{array}{l}7.82 \pm \\
4.66^{\mathrm{ab}}\end{array}$ & $\begin{array}{l}6.43 \pm 1.68 \\
b\end{array}$ & $5.63 \pm 1.05^{b}$ & $\begin{array}{l}10.00 \\
\pm 3.60 \\
a b\end{array}$ & $\begin{array}{l}8.93 \pm \\
5.42 \mathrm{bc}\end{array}$ & $\begin{array}{l}28.33 \pm \\
9.50^{b}\end{array}$ \\
\hline C 0.1 & $\begin{array}{l}5.63 \pm 1.74 \\
a b\end{array}$ & $\begin{array}{l}3.76 \pm \\
1.68 \mathrm{ab}\end{array}$ & $\begin{array}{l}3.47 \pm 1.10 \\
a\end{array}$ & $3.30 \pm 1.15^{a}$ & $\begin{array}{l}13.33 \\
\pm 3.06^{b}\end{array}$ & $\begin{array}{l}4.47 \pm \\
1.42 \mathrm{ab}\end{array}$ & $\begin{array}{l}28.33^{ \pm} \\
8.02^{b}\end{array}$ \\
\hline C 0.5 & $\begin{array}{l}2.17 \pm 0.89 \\
a\end{array}$ & $\begin{array}{l}0.77 \pm \\
0.57^{b}\end{array}$ & $\begin{array}{l}3.33 \pm 0.06 \\
a\end{array}$ & $2.90 \pm 0.17^{a}$ & $\begin{array}{l}7.33 \pm \\
6.11^{\mathrm{ab}}\end{array}$ & $\begin{array}{l}1.00 \pm \\
1.25^{a}\end{array}$ & $\begin{array}{l}12.33 \pm \\
13.05^{\mathrm{ab}}\end{array}$ \\
\hline C 1 & $\begin{array}{l}1.78 \pm 0.08 \\
\mathrm{a}\end{array}$ & $\begin{array}{l}0.40 \pm \\
0.39 a b\end{array}$ & $\begin{array}{l}2.73 \pm 0.46 \\
a\end{array}$ & $2.50 \pm 0.53^{a}$ & $\begin{array}{l}1.67 \pm \\
1.53^{a}\end{array}$ & $\begin{array}{l}0.00 \pm \\
0.00\end{array}$ & $\begin{array}{l}5.33 \pm \\
2.08^{a}\end{array}$ \\
\hline C 5 & / & / & / & l & / & / & / \\
\hline 0 & $\begin{array}{l}14.83 \pm \\
10.36^{b}\end{array}$ & $\begin{array}{l}9.65 \pm \\
8.90^{b}\end{array}$ & $\begin{array}{l}7.13 \pm 0.35 \\
d\end{array}$ & $6.90 \pm 0.20^{d}$ & $\begin{array}{l}15.67 \\
\pm \\
10.79^{\mathrm{ab}}\end{array}$ & $\begin{array}{l}13.13 \\
\pm 4.97 \\
\text { cd }\end{array}$ & $\begin{array}{l}33.00 \pm \\
17.78^{\mathrm{bcd}}\end{array}$ \\
\hline N 0.1 & $\begin{array}{l}16.60 \pm \\
3.43^{b}\end{array}$ & $\begin{array}{l}9.25 \pm \\
2.46^{b}\end{array}$ & $\begin{array}{l}6.23 \pm 1.06 \\
d\end{array}$ & $5.90 \pm 1.49 d$ & $\begin{array}{l}26.00 \\
\pm 10.82 \\
\mathrm{~b}\end{array}$ & $\begin{array}{l}14.33 \\
\pm 5.96 \\
d\end{array}$ & $\begin{array}{l}60.67 \pm \\
23.54^{d}\end{array}$ \\
\hline N 0.5 & $\begin{array}{l}8.51 \pm 1.87 \\
a b\end{array}$ & $\begin{array}{l}3.81 \pm \\
1.06 \mathrm{ab}\end{array}$ & $\begin{array}{l}5.40 \pm 0.46 \\
c d\end{array}$ & $\begin{array}{l}5.00 \pm 0.62 \\
c d\end{array}$ & $\begin{array}{l}15.67 \\
\pm \\
10.02^{\mathrm{ab}}\end{array}$ & $\begin{array}{l}7.63 \pm \\
1.31 \mathrm{bc}\end{array}$ & $\begin{array}{l}40.33 \pm \\
17.16 \mathrm{~cd}\end{array}$ \\
\hline N 1 & $\begin{array}{l}5.67 \pm 1.35 \\
\mathrm{a}\end{array}$ & $\begin{array}{l}3.35 \pm \\
0.96^{a b}\end{array}$ & $\begin{array}{l}3.13 \pm 3.10 \\
b c\end{array}$ & $\begin{array}{l}3.03 \pm 2.71 \\
\text { bc }\end{array}$ & $\begin{array}{l}8.33 \pm \\
6.66^{a}\end{array}$ & $\begin{array}{l}10.5 \\
7 \pm 2.8 \\
4 \mathrm{bcd}\end{array}$ & $\begin{array}{l}22.00 \pm \\
13.45 \\
\text { abc }\end{array}$ \\
\hline N 5 & $\begin{array}{l}2.36 \pm 0.36 \\
\text { a }\end{array}$ & $\begin{array}{l}1.02 \pm \\
0.38^{a}\end{array}$ & $\begin{array}{l}0.67 \pm 0.70 \\
\mathrm{ab}\end{array}$ & $\begin{array}{l}0.77 \pm 0.75 \\
a b\end{array}$ & $\begin{array}{l}5.00 \pm \\
3.61^{\mathrm{a}}\end{array}$ & $\begin{array}{l}4.93 \pm \\
1.16^{a b}\end{array}$ & $\begin{array}{l}9.33 \pm \\
5.13 \mathrm{ab}\end{array}$ \\
\hline N 10 & $\begin{array}{l}1.13 \pm 1.06 \\
\mathrm{a}\end{array}$ & $\begin{array}{l}0.18 \pm \\
0.16^{a}\end{array}$ & $\begin{array}{l}0.23 \pm 0.40 \\
a\end{array}$ & $0.30 \pm 0.52^{a}$ & $\begin{array}{l}0.67 \pm \\
0.58 \mathrm{a}\end{array}$ & $\begin{array}{l}1.00 \pm \\
0.92^{a}\end{array}$ & $\begin{array}{l}1.00 \pm \\
1,00^{a}\end{array}$ \\
\hline 0 & $\begin{array}{l}14.83 \pm \\
10.36^{b}\end{array}$ & $\begin{array}{l}9.65 \pm \\
8.90^{b}\end{array}$ & $\begin{array}{l}7.13 \pm 0.35 \\
c\end{array}$ & $6.90 \pm 0.20^{b}$ & $\begin{array}{l}15.67 \\
\pm 10.79 \\
b\end{array}$ & $\begin{array}{l}13.13 \\
\pm 4.97^{c}\end{array}$ & $\begin{array}{l}33.00 \pm \\
17.78^{c}\end{array}$ \\
\hline
\end{tabular}

Values are mean \pm SD for 3 replicates. Different letters show significant differences between treatment groups $(P<0.05$, LSD test). 


\begin{tabular}{|c|c|c|c|c|c|c|c|}
\hline treatment & $\begin{array}{l}\text { Whole } \\
\text { plant fresh } \\
\text { weigh(g) }\end{array}$ & $\begin{array}{l}\text { Ramet } \\
\text { fresh } \\
\text { weigh(g) }\end{array}$ & $\begin{array}{l}\text { Maximum } \\
\text { Leaf- } \\
\text { width(cm) }\end{array}$ & $\begin{array}{l}\text { Maximum } \\
\text { Leaf- } \\
\text { Length(cm) }\end{array}$ & $\begin{array}{l}\text { Ramet } \\
\text { number }\end{array}$ & $\begin{array}{l}\text { Root } \\
\text { Length } \\
\text { (cm) }\end{array}$ & $\begin{array}{l}\text { Leaf } \\
\text { number }\end{array}$ \\
\hline M 0.01 & $\begin{array}{l}7.35 \pm 4.30 \\
\mathrm{ab}\end{array}$ & $\begin{array}{l}4.62 \pm \\
1.81 \mathrm{ab}\end{array}$ & $\begin{array}{l}4.27 \pm 3.80 \\
b c\end{array}$ & $\begin{array}{l}3.90 \pm 3.57 \\
\mathrm{ab}\end{array}$ & $\begin{array}{l}9.00 \pm \\
1.00 \mathrm{ab}\end{array}$ & $\begin{array}{l}4.23 \pm \\
2.87^{a}\end{array}$ & $\begin{array}{l}20.33 \pm \\
4.04 \mathrm{bc}\end{array}$ \\
\hline M 0.1 & $\begin{array}{l}9.08 \pm 0.32 \\
a b\end{array}$ & $\begin{array}{l}5.55 \pm \\
0.82 \mathrm{ab}\end{array}$ & $\begin{array}{l}4.87 \pm 0.47 \\
c\end{array}$ & $5.17 \pm 1.24^{b}$ & $\begin{array}{l}9.00 \pm \\
3.61 \mathrm{ab}\end{array}$ & $\begin{array}{l}7.70 \pm \\
2.02 \mathrm{ab}\end{array}$ & $\begin{array}{l}19.33 \pm \\
7.23 \mathrm{bc}\end{array}$ \\
\hline M 0.5 & $\begin{array}{l}0.39 \pm 0.68 \\
a\end{array}$ & $\begin{array}{l}0.22 \pm \\
0.38^{a}\end{array}$ & $\begin{array}{l}0.53 \pm 0.92 \\
\text { a }\end{array}$ & $0.93 \pm 1.62^{a}$ & $\begin{array}{l}1.33^{ \pm} \\
2.31^{a}\end{array}$ & I & $\begin{array}{l}1.67 \pm \\
2.89^{a}\end{array}$ \\
\hline M 1 & $\begin{array}{l}1.23 \pm 0.57 \\
a\end{array}$ & $\begin{array}{l}0.67 \pm \\
0.10^{a}\end{array}$ & $\begin{array}{l}0.97 \pm 1.67 \\
a b\end{array}$ & $0.87 \pm 1.50^{a}$ & $\begin{array}{l}1.67 \pm \\
0.58^{a}\end{array}$ & l & $\begin{array}{l}4.33 \pm \\
1.53 \mathrm{ab}\end{array}$ \\
\hline M $5+0.1$ & I & / & l & / & / & I & / \\
\hline M $5+1$ & I & I & l & / & / & l & l \\
\hline
\end{tabular}

\section{2 photosynthetic pigment content}

After 14 days' exposure, the chlorophyll a, chlorophyll $b$ and total chlorophyll contents had a trend that increased at first and then decreased (Fig. 1-a, c, e). The carotenoid content also showed the same trend, it increased slightly at $\mathrm{NP} \leq 0.5 \mathrm{mg} / \mathrm{L}$ and decreased significantly at $\mathrm{NP} \geq 5 \mathrm{mg} / \mathrm{L}(\mathrm{P}<0.05$, Fig. $1 \mathrm{~g})$. Under the Cd-only stress, the chlorophyll contents in leaves of all treatments were significantly lower than those of the control $(P<0.05$, Fig. 1-a, $c, e)$. Under joint stress, photosynthetic pigment content had a similar trend.

\subsection{MDA content}

After 14 days' exposure, at the concentration of $0.1 \mathrm{mg} / \mathrm{L}$, the MDA content of NP-only stress groups was slightly higher than that of control group, while the MDA content of other groups was lower than that of control group (Fig. 2a). At the highest concentration (10 mg/L), because of the serious leaf damage, the materials were not enough to determine their contents. Under the Cd-only stress, the MDA content decreased with the increase of Cd concentrations, but did not up to significant level (Fig. 2a). Under combined stress, the MDA content had a similar tendency. No significant difference compared with the control group (Fig. 2b).

\section{4 $\mathrm{H}_{2} \mathrm{O}_{2}$ content and antioxidant enzyme activity}

\subsection{1 $\mathrm{H}_{2} \mathrm{O}_{2}$ content}


After 14 days' exposure, under the NP-only stress, the $\mathrm{H}_{2} \mathrm{O}_{2}$ content showed a tendency to increase first and then decrease. At $0.5 \mathrm{mg} / \mathrm{L}$ treatment, the $\mathrm{H}_{2} \mathrm{O}_{2}$ content had the highest value (Fig. 3a). Under the $\mathrm{Cd}$ only and combined stress, the $\mathrm{H}_{2} \mathrm{O}_{2}$ content showed a similar tendency. Under the combined stress, at $0.01+1 \mathrm{mg} / \mathrm{L} \mathrm{Cd}+\mathrm{NP}$, the $\mathrm{H}_{2} \mathrm{O}_{2}$ content had a maximum, which was significantly higher than that of the control group ( $p<0.05$, Fig. $3 b)$.

\subsubsection{SOD $\square$ CAT $\square$ POD activity}

Under the NP-only stress, Cd-only stress and combined stress, the SOD activity of $H$. dubia in all treatment groups was significantly lower than that of control group ( $p<0.05$, Fig. $4 a)$. Under the NP-only stress, the activity of CAT at $\geq 5 \mathrm{mg} / \mathrm{L}$ was significantly lower than that in the control group $(p<0.05$, Fig. $4 \mathrm{c})$. The activity of POD decreased at first and then increased with the increasing concentrations. At $1 \mathrm{mg} / \mathrm{L}$, it reached the maximum value and significantly higher than that at low concentrations $(p<0.05$, Fig. $4 e)$. The materials of the treatment groups with the highest concentration $(10 \mathrm{mg} / \mathrm{L})$ were not enough to determine the activity of each antioxidant enzymes.

Under the Cd-only stress, at $\leq 0.1 \mathrm{mg} / \mathrm{L}$, the SOD activity was significantly lower than control group ( $\mathrm{p}<$ 0.05, Fig. 4a). Under combined stress, under Cd-only and Cd + NP stress, no significant change of CAT activity between treatment groups and control group (Fig. 4c). At $0.01+0.1 \mathrm{mg} / \mathrm{L} \mathrm{Cd}+\mathrm{NP}$, the CAT activity was higher than other treatment groups $(p<0.05$, Fig. $4 d)$. Under $\mathrm{Cd}$ and combined stress, the POD activity of the treatment groups was higher than the control group, but there was no significant difference (Fig. 4e, f).

\subsection{Soluble protein content}

After 14 days of exposure, the soluble protein content increased at first and then decreased, and reached the maximum at $0.5 \mathrm{mg} / \mathrm{L}$. However, no significant difference in soluble protein content between treatment groups and control group (Fig. 5a). The soluble protein content of the $\mathrm{Cd}$ treatment groups was slightly higher than that of the control group, but none of them reached significant level. And the value reached the maximum at $1 \mathrm{mg} / \mathrm{L}$ (Fig. 5a). On the contrary, under combined stress, the soluble protein content in all the treatment groups was significantly lower than that in the control group. $(p<0.05$, Fig. $5 b)$.

\subsection{Evaluation of joint toxicity of cadmium and nonylphenol}

In this study, the inhibition rate (Table 2) of total chlorophyll content was used to evaluate the combined toxicity of Cd and NP. When Cd + NP was combined at $0.01+0.1 \mathrm{mg} / \mathrm{L}$ and $0.01+1 \mathrm{mg} / \mathrm{L}$, the RI value of total chlorophyll contents was significantly less than 1 , the results showed that there was antagonism and inhibition between the two toxicants. With the increasing treatment concentration, the RI value of total chlorophyll content was significantly higher than 1 under combined pollution of higher concentrations $\mathrm{Cd}+\mathrm{NP}(0.5+0.1 \mathrm{mg} / \mathrm{L}$ and $0.5+1 \mathrm{mg} / \mathrm{L})$. Results showed that the joint effect of the two toxicants on $\mathrm{H}$. dubia was synergistic. Under the stress of the highest concentrations $(5+0.1 \mathrm{mg} / \mathrm{L}$ and 5 $+1 \mathrm{mg} / \mathrm{L})$, the plants died completely. 
Table 2

The observed total chlorophyll inhibition in $H$. dubia exposed to $\mathrm{Cd}$, NP and their mixture (mean $\pm \mathrm{SD}, \mathrm{n}=$ $3)$.

\begin{tabular}{|c|c|c|c|c|c|c|c|}
\hline $\mathrm{Cd}(\mathrm{mg} / \mathrm{L})$ & A & $\mathrm{NP}(\mathrm{mg} / \mathrm{L})$ & B & $\begin{array}{l}\mathrm{Cd}+\mathrm{NP} \\
(\mathrm{mg} / \mathrm{L})\end{array}$ & $\begin{array}{l}\text { Observed } \\
\text { Inhibition(\%) }\end{array}$ & $\mathrm{C}_{\exp }(\%)$ & $\mathbf{R I}$ \\
\hline \multirow[t]{2}{*}{0.01} & $\begin{array}{l}33.19 \pm \\
13.85\end{array}$ & 0.1 & $\begin{array}{l}-26.61 \pm \\
24.97\end{array}$ & $0.01+0.1$ & $-22.77 \pm 25.22$ & $\begin{array}{l}15.41 \pm \\
21.10\end{array}$ & $-1.48^{x}$ \\
\hline & & 1 & $\begin{array}{l}17.45 \pm \\
15.89\end{array}$ & $0.01+1$ & $23.39 \pm 24.20$ & $\begin{array}{l}44.85 \pm \\
13.60\end{array}$ & $0.52^{\star}$ \\
\hline \multirow[t]{2}{*}{0.5} & $\begin{array}{l}26.02 \pm \\
3.70\end{array}$ & 0.1 & $\begin{array}{l}-26.61 \pm \\
24.97\end{array}$ & $0.5+0.1$ & $24.97 \pm 5.19$ & $\begin{array}{l}6.33 \pm \\
16.92\end{array}$ & $3.94^{\star}$ \\
\hline & & 1 & $\begin{array}{l}17.45 \pm \\
15.89\end{array}$ & $0.5+1$ & $79.53 \pm 3.70$ & $\begin{array}{l}41.77 \pm \\
7.41\end{array}$ & $1.90 *$ \\
\hline \multirow[t]{2}{*}{5} & 100.00 & 0.1 & $\begin{array}{l}-9.88 \pm \\
36.05\end{array}$ & $5+0.1$ & 100.00 & 100.00 & / \\
\hline & & 1 & $\begin{array}{l}61.64 \pm \\
9.07\end{array}$ & $5+1$ & 100.00 & 100.00 & / \\
\hline
\end{tabular}

\section{Discussion}

At lower concentrations, Cd, NP, Cd and NP treatments had no significant toxic effects on plant growth, even had some promoting effects. At higher concentrations, Cd, NP treatments had significant effects on plant growth. This is a typical hormesis phenomenon (Calabrese, 2005). When the concentration of Cd was $5 \mathrm{mg} / \mathrm{L}$ and the concentration of $\mathrm{Cd}+\mathrm{NP}$ was $5+0.1 / 1 \mathrm{mg} / \mathrm{L}$, the plant died in the course of cultivation due to severe poisoning. The results suggested that high Cd and NP stress inhibited plant growth, which agrees with previous studies (Wang et al., 2018). We observed plant poisoning symptoms in the experimental process: leaves from the edge to the center gradually yellowing, and then necrosis, plant root growth inhibited or even rot necrosis. The higher the concentration of the poison applied, the sooner the plant will develop these toxic symptoms. This is similar to a study by (Liu et al., 2019a). An important cause of $\mathrm{Cd}$ poisoning is its high chemical similarity with functional active ions (especially $\mathrm{Zn}$, but also $\mathrm{Ca}$ and $\mathrm{Fe}$ ) at active sites of enzymes and signal components, leading to their displacement from proteins (Gallego et al., 2012). Thus affect the absorption of many main nutrients and micronutrients, inhibit plant growth. As a hydrophobic organic compound, NP easily penetrates the cell membrane and acts on the cell's internal structure, thus stunts cell growth (Bhandari et al., 2021). A study suggests that (Shi et al., 2017), Cd and NP can affect the absorption of organisms to each other. Low concentration of NP can offer carbon source for Cd removal. Low concentration of $\mathrm{Cd}$ can change the hydrophobicity of cell membrane and increase the absorption of organic matter. However, high 
concentration of Cd-NP combined pollution can damage the permeability of cell membrane and affect the growth and metabolism of organisms.

Chlorophyll is the material basis of photosynthesis, and its content can be used as a physiological index to measure the stress resistance of plants, and is an important indicator of plants under environmental stress (Du et al., 2018). Stress of heavy metals inhibited the photosynthesis of plants. In this study, the chlorophyll $\mathrm{a}$, chlorophyll $\mathrm{b}$ and carotenoid contents in leaves of $\mathrm{Cd}$ treated groups were lower than those of control group. However, both NP alone and NP + Cd combined treatments showed a tendency of low concentration promoting chlorophyll synthesis and high concentration inhibiting chlorophyll synthesis, and the decrease was deeper than that of Cd or NP alone. It's possible that the two poisons have a synergistic effect on the plant. The results of this study are different from those of others, Shi et al. (Shi et al., 2018) studied the effects of combined Cd and NP stress on the growth and physiological indexes of ryegrass. Results showed that $0-5 \mathrm{mg} / \mathrm{L} \mathrm{NP}$ had no significant effects to the chlorophyll contents, but $0-$ $10 \mathrm{mg} / \mathrm{L} \mathrm{Cd}$ had a significant effect to the chlorophyll contents. The change trend of the chlorophyll contents of ryegrass under joint stress was the same as that under Cd-only stress. Therefore, the difference of joint toxicity effect is related to the nature and concentrations of toxicants and the treatment time, and the tolerance of different plant species and different growth stages to toxicants is also different.

Under stress or adverse environment, plants will produce reactive oxygen species (ROS) such as superoxide free radical $\left(\mathrm{O}^{-}-\right.$), hydroxyl free radical $\left(\mathrm{OH}^{-}\right)$and $\mathrm{H}_{2} \mathrm{O}_{2}$. ROS can cause oxidative damage of lipid, protein and DNA in cells and induce oxidative stress. Therefore, the production and removal of $\mathrm{H}_{2} \mathrm{O}_{2}$ in plant tissues under adversity can indirectly reflect the degree of plant damage caused by toxicants and the resistance of plants. When a large number of free radicals accumulated on the membrane, MDA as a reaction product began to accumulate. MDA can reflect the degree of cell damage, cell metabolism disorders, resulting in decreased plant biomass and leaves chlorosis and other toxic symptoms (Malik et al., 2021). $\mathrm{H}_{2} \mathrm{O}_{2}$ is an active oxygen molecule in organism and an important signaling molecule in response to stress, which is involved in plant resistance response (Yang et al., 2018). Our study showed that under $\mathrm{Cd}$ and NP alone or combined treatment, the MDA content at low concentration $(0.01+0.1$ $\mathrm{mg} / \mathrm{L}$ ) was not significantly different from that in control group, but significantly decreased under high concentrations stress. Under compound stress, the MDA content was lower than that of single stress, it could be the combination of pollution making it more toxic. This indicated that $H$. dubia had some resistance and adaptability to $\mathrm{Cd}$ and NP at low concentrations. Cell protection systems were activated at high concentrations, which eliminated the free radicals and reduced the MDA content. Under Cd-NP stress, the $\mathrm{H}_{2} \mathrm{O}_{2}$ content in the treatment groups was higher than that of the control. The increase of $\mathrm{H}_{2} \mathrm{O}_{2}$ content indicates that the original balance of active oxygen metabolism is destroyed.

In bad environment, plants have formed a set of effective oxidation defense mechanisms and highly complex detoxification mechanisms, namely enzymatic and nonenzymatic antioxidant protection systems (Wei et al., 2009). They protect plants from ROS. CAT, POD and SOD are three important defense 
enzymes in plants antioxidant systems (Shakir et al., 2018). SOD as the first line of defense for plant cells to eliminate ROS and catalyze the disproportionation of $\mathrm{O}^{2-}$ to form $\mathrm{H}_{2} \mathrm{O}_{2}$ and $\mathrm{O}_{2}$. CAT is a hemecontaining protease that catalyzes $\mathrm{H}_{2} \mathrm{O}_{2}$ produced during photorespiration, mitochondrial electron transport and fatty acid oxidation, and converts $\mathrm{H}_{2} \mathrm{O}_{2}$ to $\mathrm{H}_{2} \mathrm{O}$ and $\mathrm{O}_{2}$. POD is an enzyme that uses $\mathrm{H}_{2} \mathrm{O}_{2}$ as an electron acceptor to catalyze the oxidation of substrates to produce $\mathrm{H}_{2} \mathrm{O}$ (Liu et al., 2019b). In this study, 14 days after $\mathrm{Cd}$ and NP treatment, the POD activity in the leaves of $H$. dubia was significantly increased at high concentrations $(\geq 0.5 \mathrm{mg} / \mathrm{L})$, especially in the joint treatment. The CAT activity in $0.5+$ $0.1 \mathrm{mg} / \mathrm{L}$ and $0.5+1 \mathrm{mg} / \mathrm{L}$ was significantly lower than that in the single exposure groups. The activity of SOD decreased at first and then increased in the alone treatment, and decreased significantly in the joint treatment. In general, alone and joint exposure of $\mathrm{Cd}$ and NP resulted in the decrease of SOD and CAT activity and the increase of POD activity in leaf tissues of $\mathrm{H}$. dubia. It indicated that the antioxidant systems were damaged to some extent, and the combined stress aggravated the plant injury, caused the plant cell metabolism disorder. Previous studies have also demonstrated that $\mathrm{Cd}$ and NP combined stress can significantly increase oxidative stress levels in Chlorella sorokiniana, and the mixed toxicity showed synergistic effects of SOD and CAT activities (Wang et al., 2018). POD plays a major protective role, which can make up for the decline of CAT activity when plants are subjected to oxidative stress, and plays a major role in scavenging reactive oxygen species, the change trend of $\mathrm{H}_{2} \mathrm{O}_{2}$ content in plant leaves was the same as that of POD activity. SOD activity was negatively correlated with $\mathrm{Cd}$ content in the leaves of $H$. dubia, which was similar to the results of Yang (Yang et al., 2017). The decrease of CAT activity under single stress and the positive response of CAT in low concentration combined exposure may be related to the synergistic effect of $\mathrm{Cd}$ and NP on $\mathrm{H}$. dubia. Because of the strong oxidative stress, the plant was damaged, the protective systems were damaged and the protein was inactivated in the higher concentration of the combined poison. The results also showed that CAT played different roles under different pollutant stress, and enhanced CAT activity could help to eliminate excessive $\mathrm{H}_{2} \mathrm{O}_{2}$ in a certain concentration range. But when the concentration exceeded this threshold, the activity of CAT was inhibited when the oxidative stress caused by high concentrations of poison exceeded the resistance of enzyme. The increase of POD activity indicated that Cd + NP stress could accelerate the senescence of $H$. dubia. Our results showed that POD is more sensitive than CAT to remove $\mathrm{H}_{2} \mathrm{O}_{2}$ produced by $\mathrm{Cd}$ and $\mathrm{NP}$, and $\mathrm{H}_{2} \mathrm{O}_{2}$ is eliminated mainly by POD or other enzymes (such as $\mathrm{GSH}$ ) and nonenzymes (such as ASA).

Soluble protein in cells are mostly enzymes involved in metabolism and are an important indicator of metabolic intensity in plants (Wang et al., 2013). In this study, 14 days after being exposed to NP alone and $\mathrm{Cd}+\mathrm{NP}$, the soluble protein content in plant leaves increased first and then decreased with the increase of toxic concentrations. The soluble protein content was lower at the combined stress than that of the single treatment. This is similar to the findings of Mao and Yang (Mao and Yang, 2019). The decrease of soluble protein content in plant tissues indicated that the stress degree was enhanced under combined stress.

\section{Conclusion}


We conclude that, (1) under the NP-only stress, the minimum concentration $(0.1 \mathrm{mg} / \mathrm{L})$ of NP could promote the growth of $\mathrm{H}$. dubia, but with the increase of the stress concentrations, the toxicity of NP to $H$. dubia gradually increased. (2) Under the Cd-only stress, $H$. dubia showed a dose-dependent effect. With increasing $\mathrm{Cd}$ concentrations, the damage degree of growth indexes of $\mathrm{H}$. dubia was increased, and the chlorophyll content decreased significantly. (3) Under 14 days of combined Cd + NP stress, the growth indexes of $H$. dubia showed victim responses. Especially under $0.5+0.1 \mathrm{mg} / \mathrm{L}$ and $0.5+1 \mathrm{mg} / \mathrm{L}$, the plant fresh weight, the number of leaves and the number of remat decreased significantly, and the combined pollution had a strong toxic effect on the root of the plant. (4) At $0.01+0.1 \mathrm{mg} / \mathrm{L}$ and $0.01+1 \mathrm{mg} / \mathrm{L}$, the combined toxicity of $\mathrm{Cd}$ and NP was antagonistic to $H$. dubia. At $0.5+0.1 \mathrm{mg} / \mathrm{L}$ and $0.5+1 \mathrm{mg} / \mathrm{L}$, Cd and NP had a strong synergistic effect on $\mathrm{H}$. dubia. In the treatment groups, the lowest Cd and NP concentrations were close to the corresponding ambient concentrations $(0.003-0.03 \mathrm{mg} / \mathrm{L}$ and 0.000458-0.18 mg/L, respectively) (Islam et al., 2015). Our study shows that Cd and NP combined exposure can cause growth inhibition and ecotoxicological effects on aquatic plants even at environment-related concentrations. So, more attention should be paid to the combined effects of various pollutants.

\section{Declarations}

\section{Ethical Approval}

All the authors declare that this study does not contain any studies with human participants or animals performed.

\section{Consent to participate}

Not applicable

\section{Consent to publish}

Not applicable

\section{Authors' contribution statements:}

Zhen Ke: Investigation, Methodology, Resources, Software, Validation, Writing - review \&editing. Donghan Wang: Conceptualization, Data curation, Formal analysis, Writing - original draft. Zhonghua Wu: Supervision, Project administration, Funding acquisition.

\section{Funding}

The National Natural Science Foundation of China (No. 31270410 and No. 30970303)

\section{Competing interests}

The authors declare that there is no conflict of interests. 
Acknowledgments

This research was funded by the National Natural Science Foundation of China (No. 31270410 and No. 30970303).

\section{Availability of data and materials}

Not applicable.

\section{References}

1. Bhandari G, Bagheri AR, Bhatt P, Bilal M (2021) Occurrence, potential ecological risks, and degradation of endocrine disrupter, nonylphenol, from the aqueous environment. Chemosphere 275:130013. https://doi.org/10.1016/j.chemosphere.2021.130013

2. Bradford MM (1976) A rapid and sensitive method for the quantitation of microgram quantities of protein utilizing the principle of protein-dye binding. Anal Biochem 72:248-254. https://doi.org/10.1016/0003-2697(76)90527-3

3. Calabrese EJ (2005) Paradigm lost, paradigm found: The re-emergence of hormesis as a fundamental dose response model in the toxicological sciences. Environ Pollut 138:378-411. https://doi.org/10.1016/j.envpol.2004.10.001

4. Cang J, Zhao HJ (2013) Experimental Course of Plant Physiology. Higher Education press, Peking pp

5. Catav SS, Genc TO, Oktay MK, Kucukakyuz K (2020) Cadmium toxicity in wheat: Impacts on element contents, antioxidant enzyme activities, oxidative stress, and genotoxicity. Bull Environ Contam Toxicol 104:71-77. .https://doi.org/10.1007/s00128-019-02745-4

6. Chaudhary E, Sharma P (2019) Chromium and cadmium removal from wastewater using duckweed Lemna gibba L. and ultrastructural deformation due to metal toxicity. Int J Phytoremediat 21:279286. https://doi.org/10.1080/15226514.2018.1522614

7. Chellaiah ER. Cadmium (heavy metals) bioremediation by Pseudomonas aeruginosa: a minireview. Applied Water Science 2018; 8. https://doi.org/10.1007/s13201-018-0796-5

8. Deng ZH, Li N, Jiang HL, Lin JM, Zhao RS. Pretreatment techniques and analytical methods for phenolic endocrine disrupting chemicals in food and environmental samples. Trac-Trend Anal Chem 2019; 119. https://doi.org/ARTN 115592

9. Du Y, Wang J, Zhu F, Mai D, Xiang Z, Chen J et al (2018) Comprehensive assessment of three typical antibiotics on cyanobacteria (Microcystis aeruginosa): The impact and recovery capability. Ecotoxicol Environ Saf 160:84-93. https://doi.org/10.1016/j.ecoenv.2018.05.035

10. Gallego SM, Pena LB, Barcia RA, Azpilicueta CE, lannone MF, Rosales EP et al (2012) Unravelling cadmium toxicity and tolerance in plants: Insight into regulatory mechanisms. Environ Exp Bot 83:33-46. https://doi.org/10.1016/j.envexpbot.2012.04.006 
11. Gao P, Li Z, Gibson M, Gao H (2014) Ecological risk assessment of nonylphenol in coastal waters of China based on species sensitivity distribution model. Chemosphere 104:113-119. https://doi.org/10.1016/j.chemosphere.2013.10.076

12. Gatidou G, Thomaidis NS (2007) Evaluation of single and joint toxic effects of two antifouling biocides, their main metabolites and copper using phytoplankton bioassays. Aquat Toxicol 85:184191. https://doi.org/10.1016/j.aquatox.2007.09.002

13. Islam MS, Ahmed MK, Raknuzzaman M, Habibullah-Al-Mamun M, Islam MK (2015) Heavy metal pollution in surface water and sediment: A preliminary assessment of an urban river in a developing country. Ecol Indic 48:282-291. https://doi.org/10.1016/j.ecolind.2014.08.016

14. Jampeetong A, Brix H (2009) Nitrogen nutrition of Salvinia natans: Effects of inorganic nitrogen form on growth, morphology, nitrate reductase activity and uptake kinetics of ammonium and nitrate. Aquat Bot 90:67-73. https://doi.org/10.1016/j.aquabot.2008.06.005

15. Kersten G, Majestic B, Quigley M (2017) Phytoremediation of cadmium and lead-polluted watersheds. Ecotoxicol Environ Saf 137:225-232. https://doi.org/10.1016/j.ecoenv.2016.12.001

16. Liu JX, Ou XB, Wang JC (2019a) Physiological-Ecological responses of Naked Oat to Cadmium(Cd) stress and Cd accumulation. Journal of Triticeae Crops 39:621-629

17. Liu Y, Pang Y, Yang L, Ning S, Wang D, Wu Z. Responses of Hydrocharis dubia (BI.) Backer and Trapa bispinosa roxb. to tetracycline exposure. Ecotoxicol Environ Saf 2020; 202: 110890. https://doi.org/10.1016/j.ecoenv.2020.110890

18. Liu YF, Wang WW, Zu YX, Mei Y, Zhang JQ, Wu YC et al (2019b) Research progress on the effects of catalase on plant stress tolerance. Barley Cereal Sciences 01:5-8

19. Malik B, Pirzadah TB, Tahir I, Hakeem KR, Rather IA, Sabir JSM et al (2021) Lead and aluminiuminduced oxidative stress and alteration in the activities of antioxidant enzymes in chicory plants. Sci Hortic-amsterdam 278:109847. https://doi.org/10.1016/j.scienta.2020.109847

20. Mao XF, Yang J (2019) Physiological and biochemical characteristics of 4 farmland weeds under Zn and $\mathrm{Cd}$ stress and accumulation characteristics of heavy metals. Journal of Southwest Fprestry University 6:9-18

21. Melignani E, Faggi AM, de Cabo LI (2019) Growth, accumulation and uptake of Eichhornia crassipes exposed to high cadmium concentrations. Environ Sci Pollut Res Int 26:22826-22834. https://doi.org/10.1007/s11356-019-05461-y

22. Pretorius E, Olumuyiwa-Akeredolu OO, Mbotwe S, Bester J (2016) Erythrocytes and their role as health indicator: Using structure in a patient-orientated precision medicine approach. Blood Rev 30:263-274. https://doi.org/10.1016/j.blre.2016.01.001

23. Rehman K, Fatima F, Waheed I, Akash MSH (2018) Prevalence of exposure of heavy metals and their impact on health consequences. J Cell Biochem 119:157-184. https://doi.org/10.1002/jcb.26234

24. Rizwan M, Meunier JD, Davidian JC, Pokrovsky OS, Bovet N, Keller C (2016) Silicon alleviates Cd stress of wheat seedlings (Triticum turgidum L. cv. Claudio) grown in hydroponics. Environ Sci Pollut R 23:1414-1427. https://doi.org/10.1007/s11356-015-5351-4 
25. Shakir SK, Irfan S, Akhtar B, Rehman SU, Daud MK, Taimur N et al (2018) Pesticide-induced oxidative stress and antioxidant responses in tomato (Solanum lycopersicum) seedlings. Ecotoxicology 27:919-935. https://doi.org/10.1007/s10646-018-1916-6

26. Shi GY, Cheng YY, Shi WL (2017) Effect of Cadmium on biodegradation of Nonylphenol by Pseudomonas aeruginosa. Environmental Science 1:294-300

27. Shi GY, Li ZY, Zhang L, Cheng YY, Chen HW, Shi WL (2018) Physiological responses of Ryegrass in Cadmium- Nonylphenol Co-contaminated water and the phytoremediation effects. Environmental Science 10:4512-4518

28. Sun J, Yang X, Shen H, Xu Y, Zhang A, Gan J (2021) Uptake and metabolism of nonylphenol in plants: Isomer selectivity involved with direct conjugation. Environ Pollut 270:116064. https://doi.org/10.1016/j.envpol.2020.116064

29. Toyama T, Hanaoka T, Tanaka Y, Morikawa M, Mori K (2018) Comprehensive evaluation of nitrogen removal rate and biomass, ethanol, and methane production yields by combination of four major duckweeds and three types of wastewater effluent. Bioresour Technol 250:464-473. https://doi.org/10.1016/j.biortech.2017.11.054

30. Wang F, Chang PP, Chen YP, Peng YL, Fang YF, Wang HN (2013) Effect of exogenous nitric oxide on seedling growth and physiological characteristics of maize seedling under cadmium stress. Acta pratacultueae sinica 22:178-186

31. Wang L, Kang Y, Liang S, Chen D, Zhang Q, Zeng L et al (2018) Synergistic effect of co-exposure to cadmium (II) and 4-n-nonylphenol on growth inhibition and oxidative stress of Chlorella sorokiniana. Ecotoxicol Environ Saf 154:145-153. https://doi.org/10.1016/j.ecoenv.2018.02.039

32. Wei J, Guo J, Zhang Q, Li K, Bai L (2009) Effect of ultraviolet radiation on the antioxidant enzymes and the membrane systems of Arabidopsis Thaliana leaves. Journal of Henan University(Natural Science) 35:500-504

33. Yan Y, Sun Q, Yang J, Zhang X, Guo B (2021) Source attributions of Cadmium contamination in rice grains by Cadmium isotope composition analysis: A field study. Ecotoxicol Environ Saf 210:111865. https://doi.org/10.1016/j.ecoenv.2020.111865

34. Yang B, He J, Ren Y, Wang Y, Tian D (2018) Alleviating effect of hydrogen peroxide on seed germination of rice under cadmium stresss. Plant Physiology Journal 54:1111-1118

35. Yang HY, Wu WL, Li WL, Shi GX (2017) Accumulation and physiological response of cadmium in Hydrocharis dubia. Biologia 72:145-152. https://doi.org/10.1515/biolog-2017-00013

36. Yang L, Fang Z (2012) Effects of estradiol, nonylphenol, polychlorinated biphenyls, cadmium and zinc on the activity of superoxide dismutase in Tanichthys albonubes. Acta Laboratorium Animalis Scientia Sinica 20:38-46

37. Yang W, Gao X, Wu Y, Wan L, Lu C, Huang J et al (2021) Chemical- and species-specific toxicity of nonylphenol and octylphenol to microalgae Chlorella pyrenoidosa and Scenedesmus obliquus. Environ Toxicol Pharmacol 81:103517. https://doi.org/10.1016/j.etap.2020.103517 
38. Ye Z, Chen J, Gao L, Liang Z, Li S, Li R et al (2020) ${ }^{210} \mathrm{~Pb}$ dating to investigate the historical variations and identification of different sources of heavy metal pollution in sediments of the Pearl River Estuary, Southern China. Mar Pollut Bull 150:110670.

https://doi.org/10.1016/j.marpolbul.2019.110670

39. Zheng R, Zhang Y, Fang C, Chen M, Hong F, Bo J (2019) Joint effects of chronic exposure to environmentally relevant levels of nonylphenol and cadmium on the reproductive functions in male rockfish Sebastiscus marmoratus. Comp Biochem Physiol C Toxicol Pharmacol 215:25-32. https://doi.org/10.1016/j.cbpc.2018.09.006

40. Zhong G, Wu Z, Liu N, Yin J (2018) Phosphate alleviation of glyphosate-induced toxicity in Hydrocharis dubia (BI.) Backer. Aquat Toxicol 201:91-98.

https://doi.org/10.1016/j.aquatox.2018.05.025

41. Zhou X, Yang Z, Luo Z, Li H, Chen G (2019) Endocrine disrupting chemicals in wild freshwater fishes: Species, tissues, sizes and human health risks. Environ Pollut 244:462-468. https://doi.org/10.1016/j.envpol.2018.10.026

42. Zhou YY, Chen M, Zhao FR, Mu D, Zhang ZB, Hu JY (2015) Ubiquitous occurrence of chlorinated byproducts of bisphenol $A$ and nonylphenol in bleached food contacting papers and their implications for human exposure. Environ Sci Technol 49:7218-7226. https://doi.org/10.1021/acs.est.5b00831

\section{Figures}

a

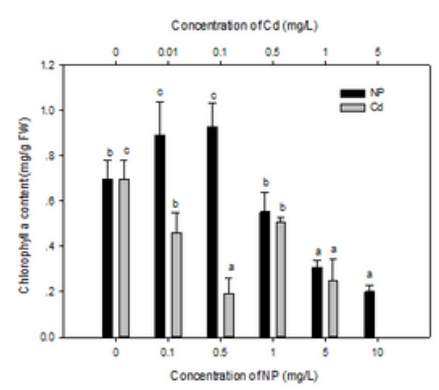

。

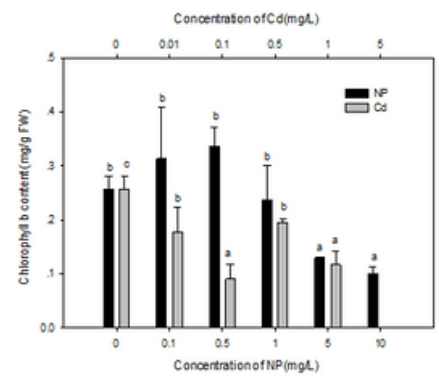

b

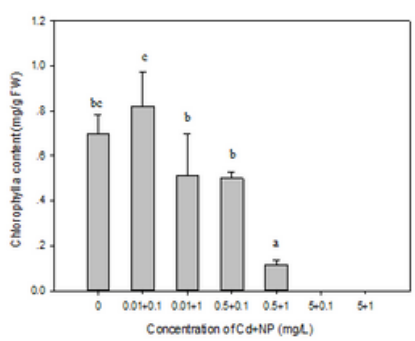

d

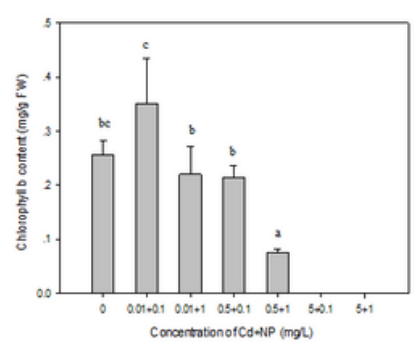

e

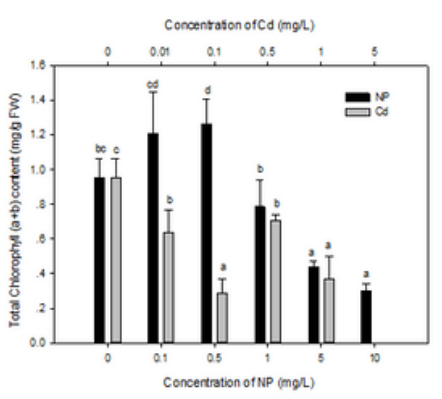

g

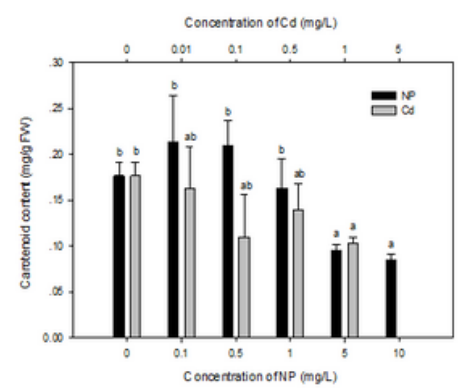

f

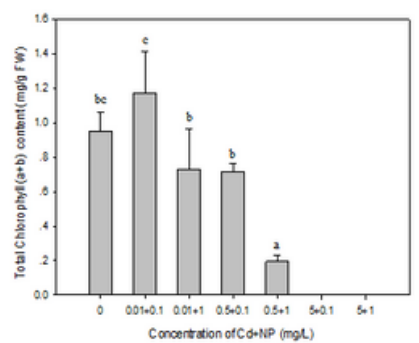

h

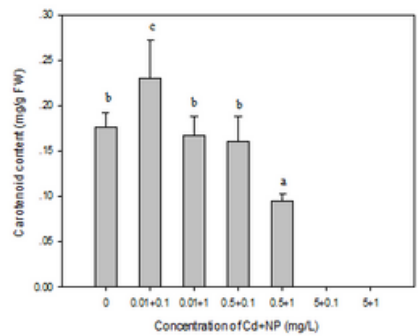

Figure 1 
The effects of Cd, NP and Cd + NP on photosynthetic pigments of $\mathrm{H}$. dubia after 14 day's exposure. Different letters in the bar show significant differences between treatment groups ( $P<0.05, L S D$ test).

a

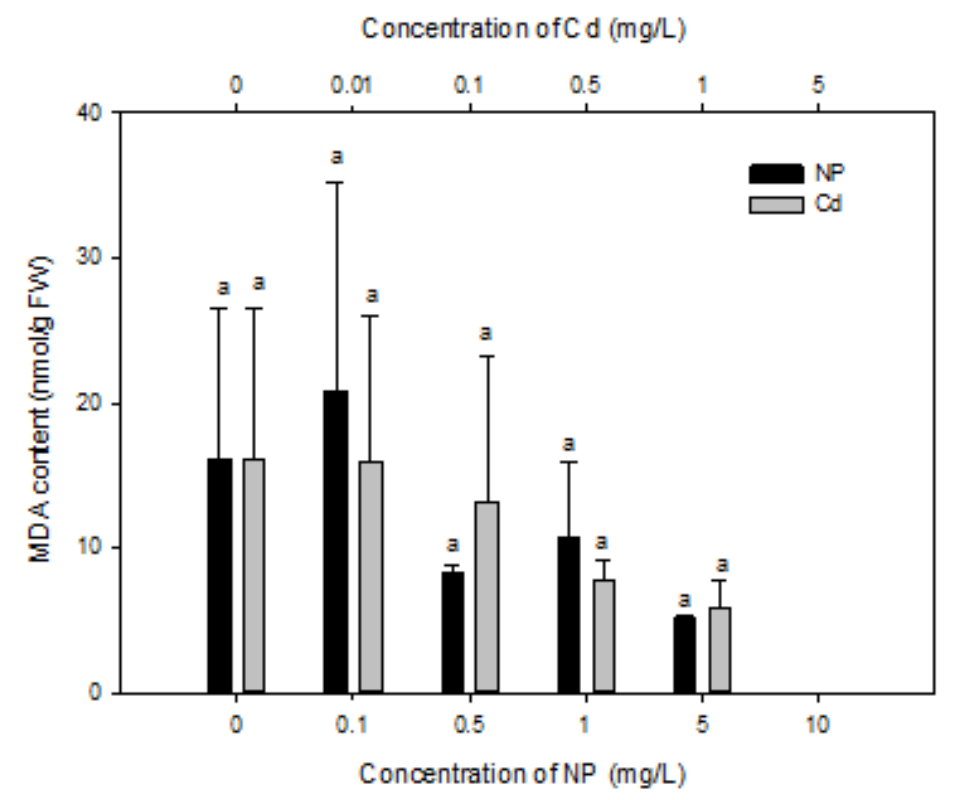

$\mathrm{b}$

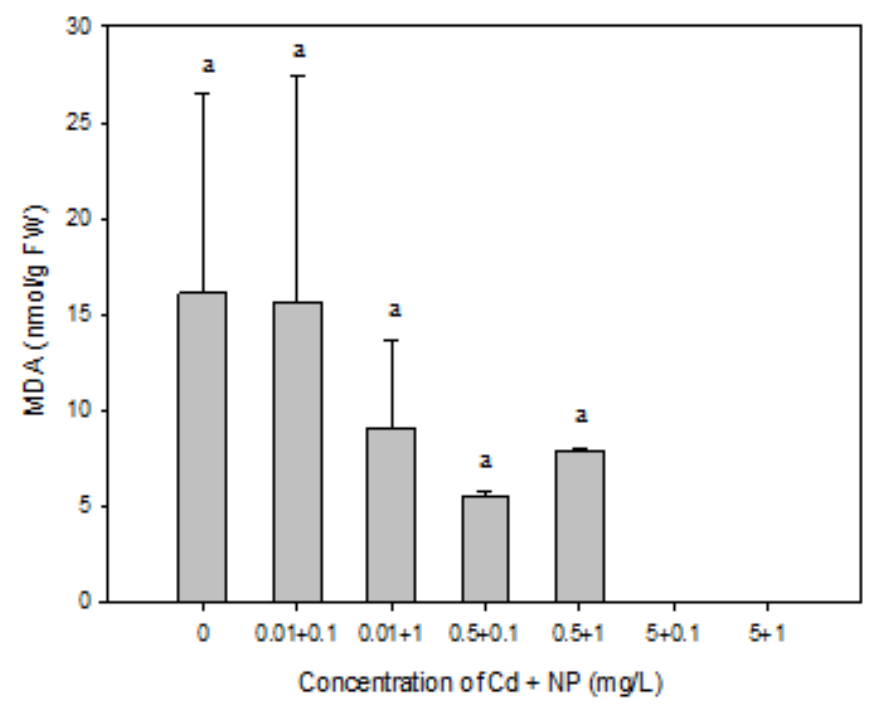

Figure 2

The effects of Cd, NP and Cd + NP on MDA content of H. dubia after 14 day's exposure. Different letters in the bar show significant differences between treatment groups $(P<0.05$, LSD test).

a

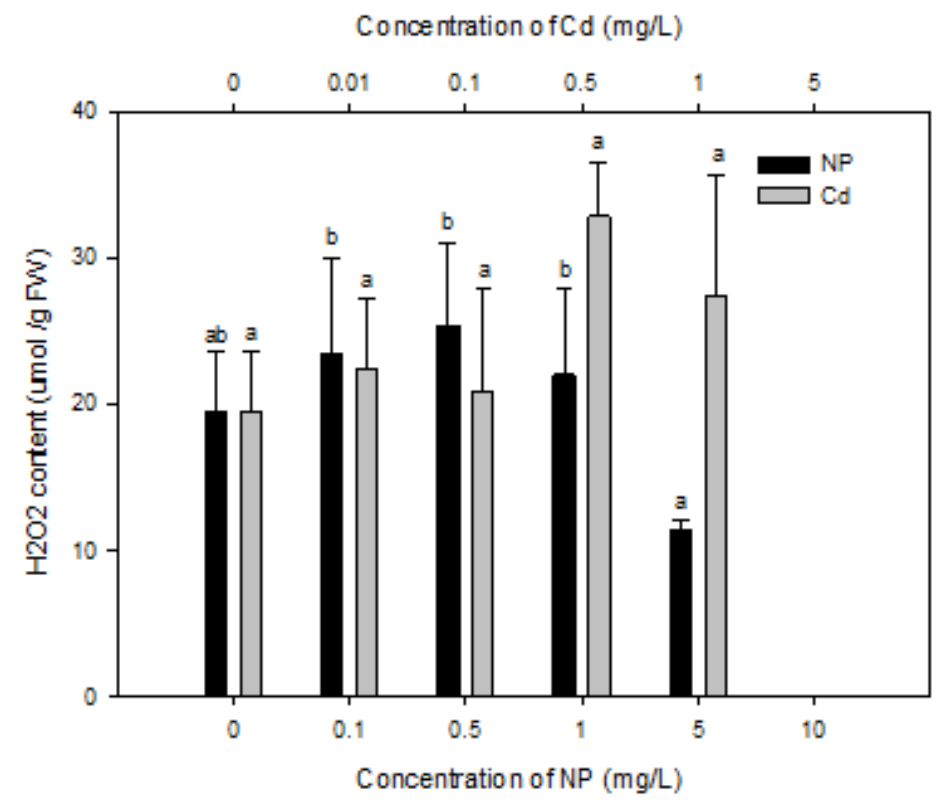

$\mathrm{b}$

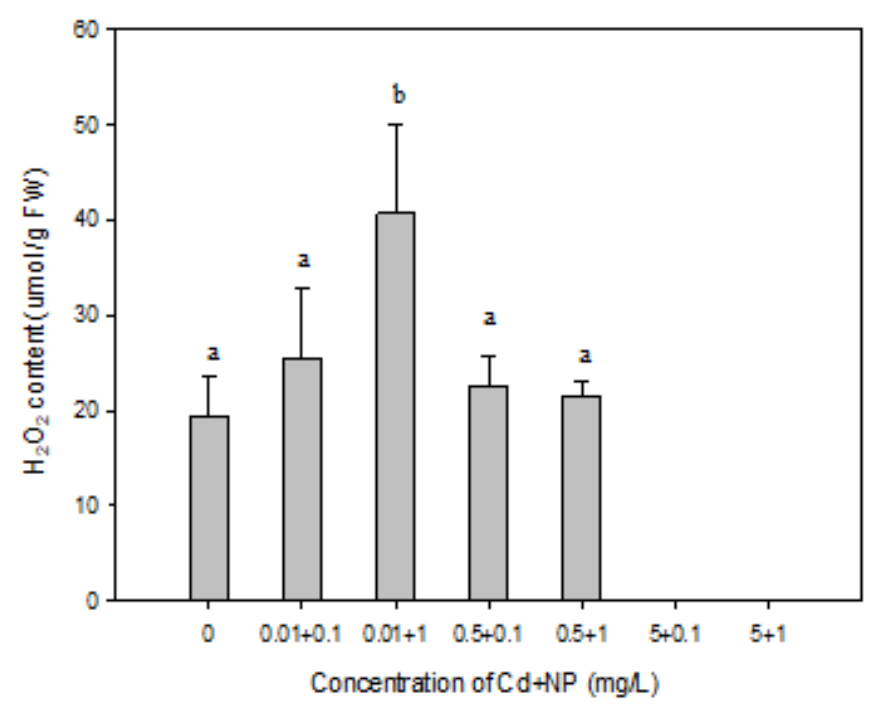

Figure 3 
The effects of Cd, NP and Cd + NP on H2O2 content of H. dubia after 14 day's exposure. Different letters in the bar show significant differences between treatment groups $(P<0.05$, LSD test).
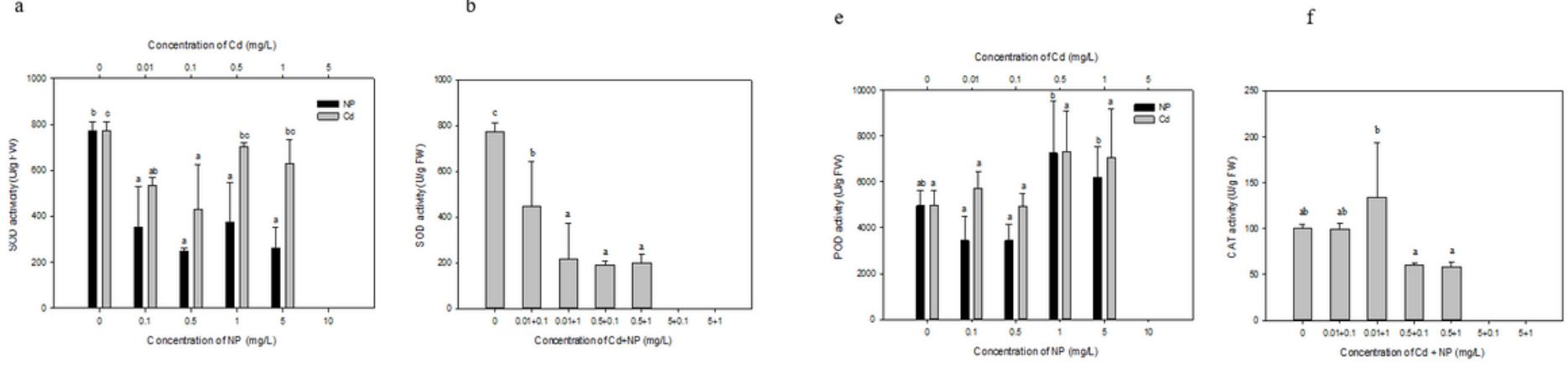

g
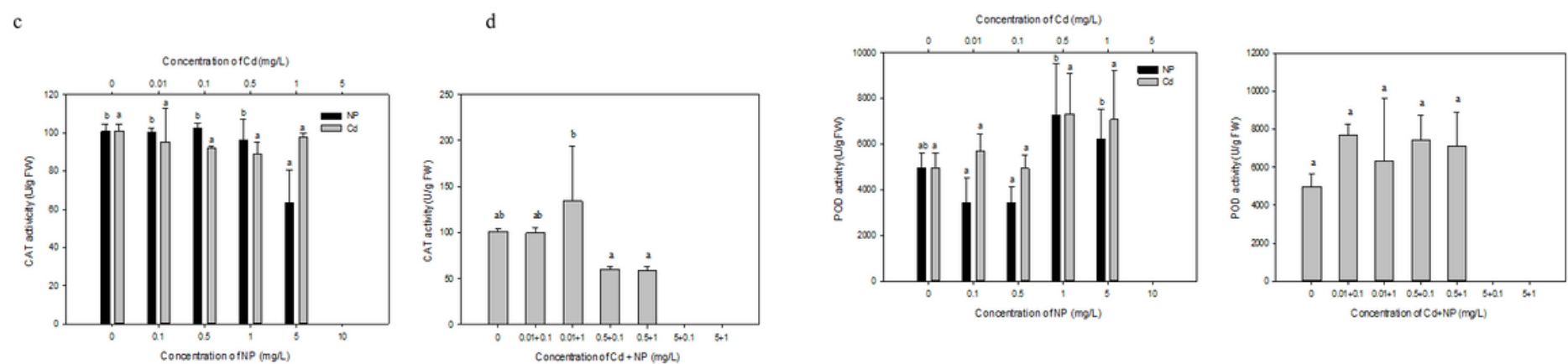

Figure 4

The effects of Cd, NP and Cd + NP on SOD, CAT, POD activity of H. dubia after 14 day's exposure. Different letters in the bar show significant differences between treatment groups ( $P<0.05$, LSD test).

a

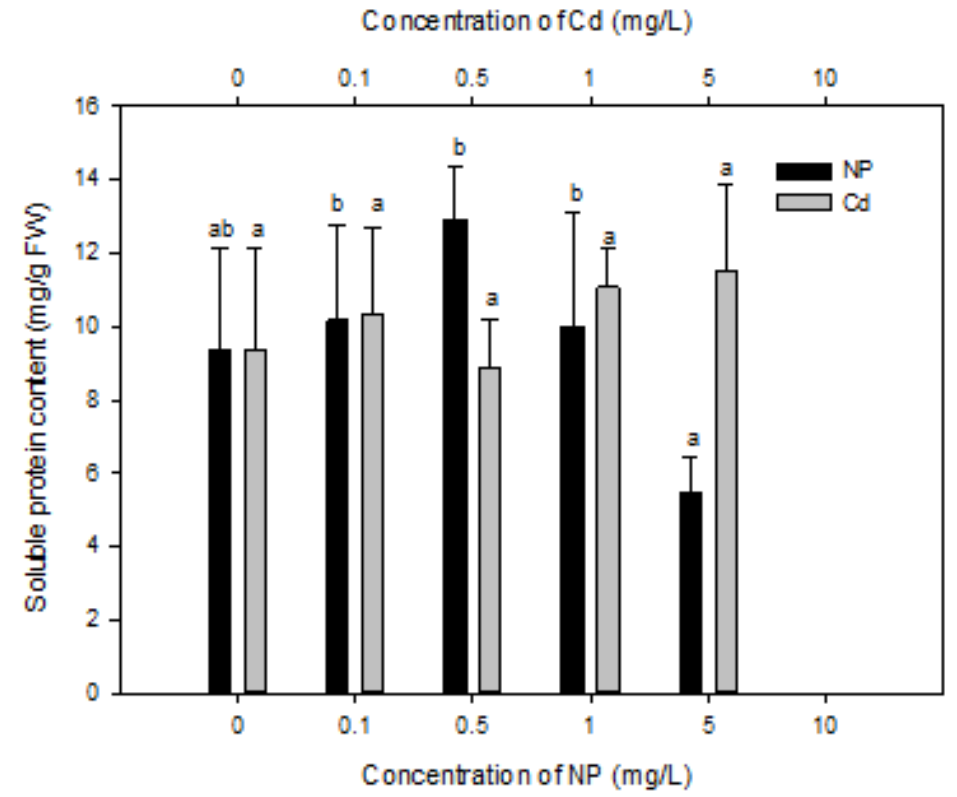

$\mathrm{b}$

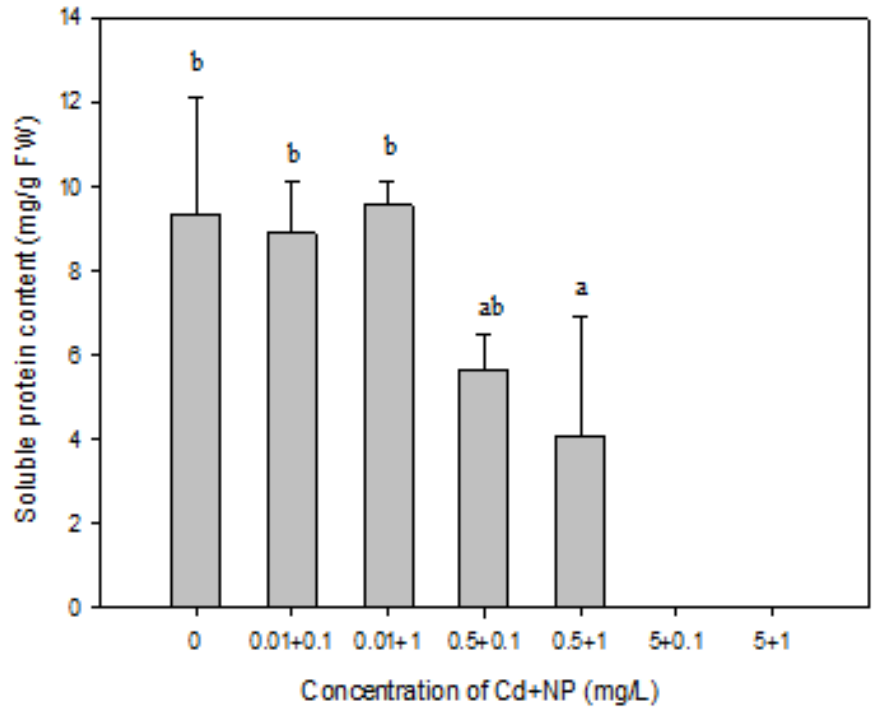

Figure 5 
The effects of Cd, NP and Cd + NP on the soluble protein content of H. dubia after 14 day's exposure. Different letters in the bar show significant differences between treatment groups $(P<0.05, L S D$ test). 